indicate the existence of a hole in the molecule of a globular protein?

Department of Electronmicroscopy,

$$
\text { K. Deutsch }
$$

University, Greifswald.

J. Segal

A. KaLAIDJIEY

Department of General Biology, University, Berlin.

${ }^{1}$ Segal, J., Dornberger, K., Kalaidjiev, A., Globular Protein Molecutes (Deutscher Verlag der Wissensehaft, Berlin; and Pergamon Press, London, 1960).

2 Hall, C. E., Biophys. Biochem. Cytol., 7, 613 (1960).

${ }^{3}$ Hall, C. E., J, Biol. Chem., 185, 45 (1950).

4 Wyckoff, R. W. G., and Labaw, L. W., Exp. Cell Res., Supp. 3, 395 (1955).

5 Dawson, I. M., Nature, 168, 241 (1951).

' Barker, C. D., and Deutseh, K., Exp. Cell Res., 15, 604 (1958).

' Kratky, O., and Kreutz, W., Angew. Chem., 70, 134 (1958).

\section{Separation of Catecholamines by Paper Chromatography}

ONE of the difficulties encountered in investigating the metabolism and distribution of catecholamines has been the inadequate separation and isolation of these substances from tissue extracts ${ }^{1}$. Various solvent systems have been used for developing chromatograms of the catecholamines ${ }^{2-4}$; but none has effected a complete separation. The method described here involves a novel technique of $180^{\circ}$ solvent-reversal paper chromatography utilizing two different solvent systems, which makes possible separation of 3,4-dihydroxyphenylalanine (dopa), 3-hydroxytyramine (dopamine), norepinephrine, epinephrine, and 3,4-dihydroxyphenylacetic acid, on a single paper strip.

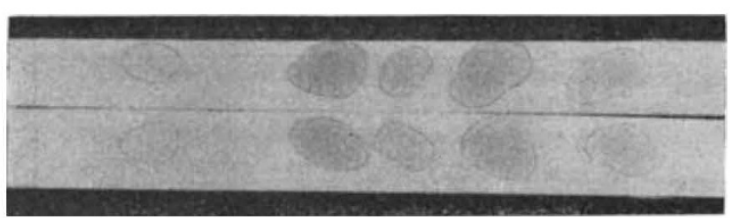

Fig. 1. Separation of catecholamines. From left to right norepinephrine; 3-hydroxytyramine ; epinephrine

Approximately $25 \mu \mathrm{gm}$. of each of five catecholamines, dissolved in 1 per cent hydrochloric acid in 95 per cent ethanol ${ }^{5}$, were spotted $7 \mathrm{~cm}$. from the end of a strip or sheet of Whatman No. 1 filter paper, 57 $\mathrm{cm}$. in length. The papers were developed by the descending technique for $28 \mathrm{hr}$. with an 88 per cent aqueous solution of phenol in an atmosphere of $1 \mathrm{~N}$ hydrochloric acid. The chromatograms were washed with benzene to remove the phenol and allowed to dry completely. The papers were then redeveloped with $n$-butanol saturated with $1 N$ hydrochloric acid $^{3}$, again by the descending technique for $25 \mathrm{hr}$. However, the second solvent was run in a direction opposite $\left(180^{\circ}\right)$ to the phenol. After drying completely, the spots were developed by spraying with 0.44 per cent potassium ferricyanide solution in phosphate buffer $p H \mathbf{H} 7 \cdot 8$ (ref. 2). When the colours did not appear immediately, the papers were exposed to ammonia vapour to enhance their colour development. For further identification of the spots, the papers were viewed under ultra-violet light (Table 1).

The $R_{F}$ values for the individual catecholamines developed with each solvent system separately are
Table 1. Staining CHaRacteristics and $R_{F}$ Values of Cambohol. Compound Colour

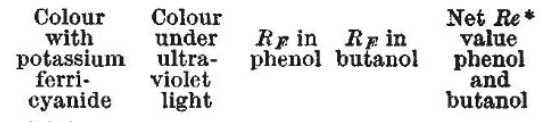

3,4-Dihydroxy $\begin{array}{llllll}\text { phenylacetic acid } & \begin{array}{c}\text { paint } \\ \text { purple }\end{array} & \text { purple } & 0.61 & 0.85 & 0.17\end{array}$ 3,4-Dihydroxy. phenylalanine (dopa) Norepinephrine purple dark purple $\quad 0.26 \quad 0.30 \quad 0.50$ 3-Hydroxytyramine
(dopamine) pink$\begin{array}{llll}\text { purple yellow } & 0.30 & 0.22 & 0.63\end{array}$

Epinephrine

purple

dark

purple $\quad \begin{array}{lll}0.48 & 0.31 & 0.78\end{array}$

pink* Re, net $R$ values based on epinephrine which was considered
arbitrarily to represent the solvent front and was given a value of 1.0 . indicated in Table 1. To separate the catecholamines, the two solvent systems were run in an opposite direction, therefore a net $R$ value (Re; based on epinephrine) was calculated for each compound. Epinephrine was considered arbitrarily to represent the solvent front and was given a value of 1.0 based on the starting line of the first solvent system. Generally, two compounds will be separated if the difference between their net $R e$ values is greater than $0 \cdot 1$. Chromatographic separation of radioactive catecholamines in tissue extracts was improved by addition of $20-40 \mu \mathrm{gm}$. of each of the corresponding carriers to the extract before application to the paper.

\section{BENJAMIN WEISS} G. VICTOR Rosst

Department of Pharmacology,

Philadelphia College of Pharmacy and Science, Philadelphis 4.

1 Vogt, M., Pharmacal. Revs., 11, 249 (1959).

2James, W. O., Nature, 161, 851 (1948).

${ }^{3}$ Hamberg, U., and von Euler, U. S., Acta chem. Scand., 4, 1185 (1950).

McGeer, E. G., Robertson, M. C., and McGeer, P. L., Canad. J. Biochem. Physiol., 39, 605 (1961).

${ }^{5}$ Goldenberg, M., Faber, M., Alston, E. J., and Chargaff, E. C., Science, $109,534(1949)$

\section{Oxygen Consumption, Lactic Acid Production and Protein Synthesis of Peritoneal Macrophages}

Ir has been shown that macrophages, obtained by injection of paraffin oil into the peritoneum of the rabbit, are facultative anaerobic cells ${ }^{1}$. In order to evaluate the ability of respiration and glycolysis to supply energy for biosyntheses in these cells, the incorporation-rate of a labelled amino-acid into protein, as a model of a synthetic process, was investigated in aerobic and anaerobic conditions ${ }^{2,3}$. At the same time, consumption of oxygen and production of lactic acid were also measured.

Table 1. Lactio Acid Production by Peritoneal Macrophages No. of $\mu$ moles $/ \mathrm{mgm} . / \mathrm{N} / \mathrm{hr} . \mu$ moles $/ 10^{6}$ cells $/ \mathrm{hr}$.

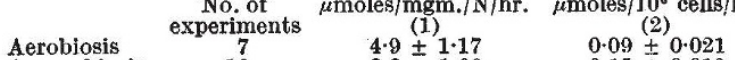
$\begin{array}{lrrr}\text { Aerobiosis } & 7 & 4.9 \pm 1.17 & 0.09 \pm 0.021 \\ \text { Anaerobiosis } & 10 & 8.2 \pm 1.09 & 0.15 \pm 0.019\end{array}$

Incubation mixture (final concentration): NaCl, 108 m.moles; $\mathrm{KCl}, 4.7 \mathrm{~m}$. moles; $\mathrm{CaCl}_{8}, 1.3 \mathrm{~m}$.moles; $\mathrm{MgSO}_{4}, 1.2 \mathrm{~m}$. moles; sodium phosphate buffer, 5.0 m.moles; sodium bicarbonate, 25.0 m.moles glucose, $15 \mathrm{~m}$.moles. Incubation lasted $60 \mathrm{~min}$. at $38^{\circ} \mathrm{C}$. in a metabolic shaking incubator. The reaction was stopped adding 10 per cent trichloroacetic acid and lactic acid was estimated by the method of Barker and Summerson (ref. 8). Gas phase: 95 per cent oxygen + 5 per cent carbon dioxide; 95 per cent
dioxide. Figures are means $\pm S . \boldsymbol{E}$.

(1) Nitrogen estimated by the Nessler method (ref. 9).

(2) Cell counts made in a Thoma-Zeiss hæmocytometer. 